\title{
Advantages and disadvantages of mechanical manure dewatering
}

\author{
Valentin Gusev*, Lyubov Zazykina, Inna Sysoeva and Valeriy Lukashenko \\ Federal State Budget Scientific Institution Federal Scientific Center 'All-Russian Research and \\ Technological Poultry Institute’ of Russian Academy of Sciences, Sergiev Posad, Russia
}

\begin{abstract}
The article provides an analysis of the performed experiments on mechanical dewatering of manure by a press and a centrifuge. It was determined that 2.5-3.5 tons of liquid can be removed from 10 tons of manure with $70 \%$ moisture. It is known that the mechanical method of removing moisture from manure saves a significant amount of thermal energy in comparison with the thermal method, which is moisture evaporation. However, along with water, nutrients dissolved in it, especially nitrogen, are removed from the manure. The subsequent use of nitrogen-depleted manure as fuel is beneficial because less nitrogen oxide is released into the atmosphere. Moreover, when coal is added to the manure, it is possible to intensify this process. Up to $44 \%$ of nitrogen, up to $41 \%$ of phosphorus and up to $35 \%$ of potassium pass into the liquid fraction. Such liquid can be used for foliar feeding of plants with a close arrangement of sowing crops. When using manure as a fertilizer, it is more expedient not to use mechanical dewatering, but to perform thermal drying with simultaneous disinfection from pathogenic microflora and weed seeds. To exclude formation of manure lumps with an outside crust and some droppings that didn't undergo disinfection, it must be pre-mixed with dry droppings or sawdust.
\end{abstract}

\section{Introduction}

Due to the uneven location of poultry farms on the territory of the Russian Federation, the density of poultry per 1 hectare reaches 5-10 livestock units, with an ecologically safe level - 2 livestock units. One livestock unit equals 1 cow. In accordance with the standards of the USSR Ministry of Agriculture of 1973, there is a conversion factor for an adult bird equal to 0.025 . One livestock unit equals 40 hens [1]. The rationale for the standard was carried out in terms of the amount of feed consumed, however, according to our calculations, in terms of the yield of basic nutrients for plants from cow manure and chicken droppings - 1 livestock unit equals 150-200 hens. Therefore, it is advisable to clarify this standard, especially for the design of new poultry farms in order to correctly calculate the required areas of agricultural land. Currently, some poultry farms have practically no agricultural land at all. Thus, surplus manure is used as compost to fertilize nearby fields. There is a problem of manure selling, especially from poultry, which is contained in cage batteries.

\footnotetext{
* Corresponding author: gusev.valentin2012@ya.ru
} 
This type of manure has a moisture content of $66-74 \%$, [2] i.e. 10 tons of manure contain up to 7.4 tons of water. It is not economically viable to transport manure with so much water over long distances. Therefore, it is advisable to dewater the manure. Another useful use of dewatered manure is as fuel. However, with traditional drying of manure, a large amount of nitrogen remains in it - up to $5.4 \%$, calculated on the dried basis. To fire such manure, installations made of corrosion-resistant materials with a complex system for cleaning flue gases from harmful nitrogen oxides are required. Challenges arise - to reduce the amount of nitrogen in the manure intended for firing, to preserve this nitrogen for the production of fertilizer, to reduce the cost of dewatering and transportation over long distances.

To solve these problems, experiments were carried out at the Federal Scientific Center 'All-Russian Research and Technological Poultry Institute' of the Russian Academy of Sciences. The costs of thermal energy and liquid fuel are known when drying manure in drum dryers up to $14 \%$ moisture depending on the moisture content of the original manure, Table 1

Table 1. Consumption of thermal energy of liquid fuel per 1 ton of dry manure in drum-type installations, depending on the moisture content of the raw material

\begin{tabular}{|c|c|c|c|c|}
\hline $\begin{array}{c}\text { Initial } \\
\text { moisture of } \\
\text { manure, \% }\end{array}$ & $\begin{array}{c}\text { Amount of } \\
\text { initial manure } \\
\text { to } \\
\text { manufacture 1 } \\
\text { ton of manure } \\
\text { with } 14 \% \\
\text { moisture, } \mathrm{kg}\end{array}$ & $\begin{array}{c}\text { Amount of } \\
\text { water required } \\
\text { to be removed } \\
\text { by } \\
\text { evaporation, } \\
\mathrm{kg}\end{array}$ & $\begin{array}{c}\text { Total heat } \\
\text { energy } \\
\text { consumption, } \\
\mathrm{kJ}\end{array}$ & $\begin{array}{c}\text { Liquid fuel } \\
\text { input, } \\
\mathrm{kg}\end{array}$ \\
\hline 90 & 8600 & 7600 & 25659500 & 555 \\
\hline 80 & 4300 & 3300 & 11141600 & 241 \\
\hline 73 & 3185 & 2185 & 7377100 & 160 \\
\hline 65 & 2457 & 1457 & 4819200 & 105 \\
\hline
\end{tabular}

Note: the values are given taking into account the drum dryer efficiency - $80 \%$.

The data from Table 1 shows that to reduce the moisture content of the manure from $73 \%$ to $14 \%, 160 \mathrm{~kg}$ of liquid fuel is needed, and from $50 \%$ to $14 \%-53 \mathrm{~kg}$, i.e. 3 times less. In this regard, it was decided to apply preliminary decrease of the moisture content of the manure from $70 \%$ to $55 \%$ by the method of mechanical dewatering. It is known that the method of mechanical dewatering of manure saves a significant amount of thermal energy in comparison with the thermal method - moisture evaporation.

\section{Mechanical manure dewatering experiments}

\subsection{Preliminary dewatering of manure with a press}

For the study, the manure obtained from laying hens of SP-789 cross, 30 weeks of age were used. Manure dewatering was carried out using a T $61210 \mathrm{M}$ press with a pressure gauge with a piston force of up to 10 tons and a TsLN-16 centrifuge with a rotation speed of up to 12 thousand rpm. Chopped straw was used as filters in the experiment of manure dewatering with a press, and a woven stainless steel mesh - in the rest of the experiments.

A diagram of the pressing process with a T612 10M press is shown in Fig. 1. 


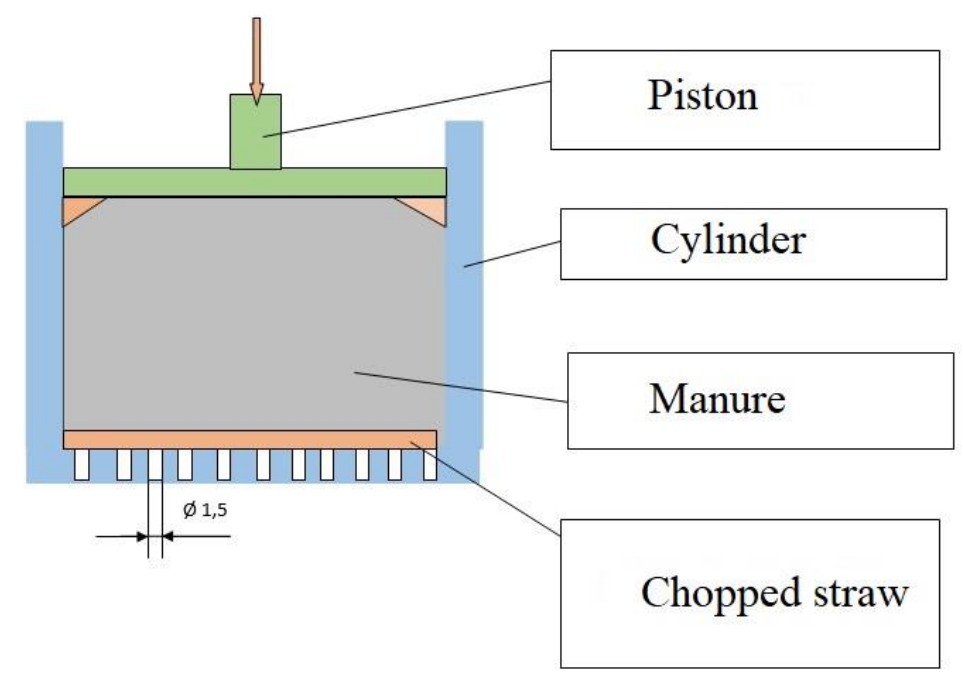

Fig. 1. Press

The results of pressing the manure with $70 \%$ moisture content are presented in Table 2.

Table 2. Results of pressing the manure.

\begin{tabular}{|c|c|c|c|c|}
\hline $\begin{array}{l}\text { Piston force, } \\
\mathrm{kg}\end{array}$ & $\begin{array}{l}\text { Pressure, } \\
\mathrm{kgf} / \mathrm{cm}^{2}\end{array}$ & $\begin{array}{l}\text { Liquid } \\
\text { fraction yield, } \\
\%\end{array}$ & $\begin{array}{l}\text { Rest of the } \\
\text { solid } \\
\text { fraction, \% }\end{array}$ & $\begin{array}{l}\text { Solid } \\
\text { fraction } \\
\text { moisture, \% }\end{array}$ \\
\hline 500 & 13 & 17.0 & 88.0 & 62.5 \\
\hline 1000 & 26 & 26.0 & 79.0 & 59.5 \\
\hline 2000 & 52 & 33.0 & 72.0 & 56.9 \\
\hline 3000 & 78 & 36.0 & 69.0 & 55.1 \\
\hline 3500 & 91 & 37.5 & 67.5 & 54.0 \\
\hline 4000 & 104 & 38.0 & 67.0 & 53.7 \\
\hline
\end{tabular}

Note: moisture content of liquid fractions is $95-97 \%$.

Conclusion: it is possible to mechanically remove 366 liters of liquid fraction from 1 ton of manure with the energy consumption for the entire dewatering process from $70 \%$ to $20 \%$, approximately 2 times less than for the removal of liquid fractions from the manure by the thermal evaporation method.

Based on the research results, a new design of the press for the first stage of dewatering of poultry manure was developed. Patent for invention No. 2728 467. Conveyor press for poultry manure dewatering [3]. In this device, the process of manure dewatering can be carried out continuously with a high productivity of $10-15 \mathrm{t} / \mathrm{h}$.

\subsection{Preliminary manure dewatering with a centrifuge}

Dewatering of manure of $70 \%$ moisture using a laboratory centrifuge TsLN 16 with a stainless steel woven mesh filter (Mesh 325 x 2300 AISI316 ASTM E2016-06). 
The results of manure dewatering with $70 \%$ moisture content using a TsLN 16 laboratory centrifuge with a stainless steel filter are shown in Table. 3 .

Table 3. Manure centrifugation results.

\begin{tabular}{|c|c|c|c|c|}
\hline $\begin{array}{c}\text { Number of } \\
\text { revolutions of } \\
\text { the centrifuge } \\
\text { rotor, rpm }\end{array}$ & $\begin{array}{c}\text { Maximum } \\
\text { movement } \\
\text { speed of } \\
\text { manure } \\
\text { adjacent to } \\
\text { the filter, } \\
\mathrm{m} / \mathrm{s}\end{array}$ & $\begin{array}{c}\text { Liquid } \\
\text { fraction yield, } \\
\%\end{array}$ & $\begin{array}{c}\text { Liquid } \\
\text { fraction } \\
\text { yield, \% }\end{array}$ & $\begin{array}{c}\text { Solid } \\
\text { fraction } \\
\text { moisture, \% }\end{array}$ \\
\hline 3000 & 25 & 14 & 86 & 65.6 \\
\hline 5000 & 42 & 28 & 72 & 59.4 \\
\hline 7500 & 63 & 34.4 & 65.6 & 56.1 \\
\hline 10000 & 84 & 36 & 64 & 55.0 \\
\hline
\end{tabular}

Note: moisture content of liquid fractions is $95-97 \%$.

The use of centrifugation with a stainless steel filter enables us to reduce manure moisture content from $70 \%$ to $55 \%$ at a maximum speed of the manure sample adjacent to the filter $-84 \mathrm{~m} / \mathrm{s}$, therefore, it is possible to remove 370 liters of liquid from 1 ton of manure by the mechanical method. To carry out this operation, you will need a centrifuge with a drum diameter of $1.0-1.2 \mathrm{~m}$ and a rotation speed of up to $1500 \mathrm{rpm}$. The power consumption is approximately $15-17 \mathrm{~kW}$.

Table 4. Indicators of the chemical composition of solid fraction.

\begin{tabular}{|c|c|c|c|}
\hline No. & Indicator name & $\begin{array}{c}\text { Control manure } \\
\text { sample }\end{array}$ & $\begin{array}{c}\text { Experimental } \\
\text { manure sample } \\
\text { after } \\
\text { centrifugation }\end{array}$ \\
\hline 1 & $\begin{array}{c}\text { Manure } \\
\text { moisture, \% }\end{array}$ & 69.68 & 58.41 \\
\hline 2 & $\begin{array}{c}\text { Amount of total } \\
\text { nitrogen, \% }\end{array}$ & 4.43 & 3.61 \\
\hline 3 & $\begin{array}{c}\text { Amount of } \\
\text { phosphorus, \% }\end{array}$ & 1.82 & 1.62 \\
\hline 4 & $\begin{array}{c}\text { Amount of } \\
\text { potassium, \% }\end{array}$ & 1.44 & 1.16 \\
\hline 5 & $\begin{array}{c}\text { Amount of } \\
\text { calcium, \% }\end{array}$ & 9.28 & 9.24 \\
\hline
\end{tabular}

During preliminary mechanical dewatering of manure by centrifugation, in addition to removing a large amount of liquid, main nutrients are also removed along with water: nitrogen, phosphorus, potassium and calcium. The largest amount of nutrients that passed into the liquid fraction - potassium - $19.4 \%$, nitrogen - $18.5 \%$, phosphorus $-11.0 \%$ and calcium $-0.4 \%$. The subsequent separate use of solid and liquid fractions as fertilizers will be difficult. Removing $18.5 \%$ of nitrogen from the manure is not enough for its subsequent use as fuel, so it was decided to add a natural adsorbent to it. 


\section{Experiment of mechanical dewatering of manure with adding natural adsorbent}

A study was also carried out with adding a natural adsorbent in the amount of $1.5 \%, 2.0 \%$ and $3.0 \%$ by weight of the dry matter. The results of manure dewatering of $70 \%$ moisture using a TsLN 16 laboratory centrifuge with a stainless steel filter are shown in Table 5.

Table 5. The results of manure dewatering

\begin{tabular}{|l|c|c|c|c|}
\hline \multirow{2}{*}{$\begin{array}{l}\text { Indicator } \\
\text { name }\end{array}$} & \multirow{2}{*}{$\begin{array}{l}\text { Control } \\
\text { manure } \\
\text { sample }\end{array}$} & \multicolumn{3}{|c|}{$\begin{array}{l}\text { Experimental samples after centrifugation } \\
\text { with adding natural adsorbent }\end{array}$} \\
\cline { 3 - 5 } & $1.5 \%$ & $2 \%$ & $3 \%$ \\
\hline $\begin{array}{c}\text { Manure } \\
\text { moisture, \% }\end{array}$ & 69.68 & 59.12 & 58.64 & 58.37 \\
\hline $\begin{array}{c}\text { Amount of } \\
\text { total nitrogen, } \\
\%\end{array}$ & 4.43 & 3.41 & 3.09 & 2.45 \\
\hline $\begin{array}{c}\text { Amount of } \\
\text { phosphorus, } \%\end{array}$ & 1.82 & 1.34 & 1.11 & 1.07 \\
\hline $\begin{array}{c}\text { Amount of } \\
\text { potassium, \% }\end{array}$ & 1.44 & 1.00 & 0.97 & 0.94 \\
\hline $\begin{array}{c}\text { Amount of } \\
\text { calcium, \% }\end{array}$ & 9.28 & 9.18 & 9.04 & 8.29 \\
\hline
\end{tabular}

Adding various doses of natural adsorbent to the original manure, before centrifugation, increases the movement of nutrients from it together with water into the liquid fraction. Moreover, the higher the dose of natural adsorbent, the more the effect of combining the solid fraction of the manure with nutrients is manifested.

\section{Conclusion}

Using mechanical dewatering of manure, it is possible to reduce its moisture content to $55 \%$. With mechanical preliminary dewatering of manure from $\sim 70 \%$ to $\sim 50 \%$, the amount of thermal energy for heating the manure $\sim$ from $20^{\circ} \mathrm{C}$ to $100^{\circ} \mathrm{C}$ is significantly reduced for evaporation of $\sim 300$ liters of water from each ton of manure. When natural adsorbent is added to the manure in an amount of $3 \%$ of the dry matter mass in the manure during dewatering, a smaller amount of microelements remains in the solid fraction of the manure.

Mechanical dewatering using natural adsorbent reduces the nitrogen content in the manure to $2.45 \%$ and brings the solid fraction of the manure closer in terms of the total nitrogen content to the previously widespread fuel - turf, in which the amount of nitrogen ranges from 0.8 to $4.0 \%$, therefore, such an operation can be applied in the process of preparing pellets or briquettes based on solid residual manure. This solid fraction of the manure can be used as an addition to other types of solid fuels.

The use of mechanical dewatering of manure intended for use as fertilizer is not rational. When performing this operation, the solid fraction is significantly depleted in nutrients, and transportation of the liquid fraction is possible only with a close location of agricultural land. The liquid fraction is used for watering or irrigation.

Consequently, the use of mechanical dewatering of manure for its subsequent use as fertilizer is not advisable. 


\section{References}

1. Order of the Ministry of Agriculture 'On standard staffs and standards of state farms, fattening farms, pedigree and stud farms of the system of the Ministry of Agriculture of the USSR' dated July 5, 1973 No. 229.

2. Guidelines for the technological design of systems for removal and preparation of manure and dung RD-APK 1.10.15.02-17, M., 2017, pp. 23-25.

3. Patent No. 2728467 Conveyor press for dewatering poultry droppings No. 2019145028: Appl. 30.12.2019: publ. 07/29/2020. Gusev V.A., Zazykina L.A., Fisinin V.I., Efimov D.N., Kavtarashvili A.Sh., Saleeva I.P., Sysoeva I.G., Borisov S.S.; applicants, patent holders of FSC 'VNITIP' RAS and LLC 'STIMUL-INK'. 